„Etnografia Polska”, t. LXIV, 2020, z. 1-2

PL ISSN 0071-1861; e-ISSN: 2719-6534

DOI: $10.23858 / \mathrm{EP} 64.2020 .004$

CC BY 4.0

HUBERT WIERCIŃSKI

Instytut Etnologii i Antropologii Kulturowej UW, Warszawa

\title{
O ZASTOSOWANIU ELEMENTÓW ETNOGRAFII PRZEDTEKSTOWEJ W BADANIU INSTYTUCJI OPIEKI MEDYCZNEJ
}

W ciągu ostatnich dekad krytyce poddane zostały metody pracy etnografów oraz pojęcie terenu - dziś jest on konstruowaną formą doświadczenia i otwartą przestrzenią, gdzie rodzą się interakcje przenoszące badaczy i badanych poza geograficzne ramy (Kairski, Buliński 2013; Rakowski 2018, s. 19-20). Choć debata metodologiczna $\mathrm{w}$ antropologii jest wielowątkowa, dotyczy przede wszystkim sposobu tworzenia wiedzy antropologicznej (Hastrup 2018, s. 116-117; Rakowski, Patzer 2018, s. 1-3). Uważam, że granice antropologicznej epistemologii, pomimo mnogości propozycji, wciąż wyznacza dziedzictwo myśli hermeneutycznej i fenomenologicznej. Oscyluje ona między czerpaniem z kulturowych kodów i znaków a zwrotem ku ciału i pozawerbalnej ekspresji otwierającej percepcję na inne źródła poznania, takie jak doświadczenie i zmysł udziału (Nycz 2018, s. 7-11; Rakowski 2018, s. 18-24; Rakowski, Patzer 2018, s. 9-16).

Niedawno, głównie za sprawą Tomasza Rakowskiego (Rakowski 2018; Rakowski, Patzer 2018), pojawiła się propozycja podejmująca się rozwiązania problemów narosłych wokó „,klasycznych” metodologii antropologicznych. Te bowiem nazbyt często traktowały ludzi jako bezosobowe formy, w których jedynie odciskały się wzory i kulturowe schematy (Turner 1986, s. 72). „Etnografia przedtekstowa”, bo o niej mowa, stawia sobie za cel przywrócenie etnograficznemu poznaniu żywego i pozatekstowego doświadczenia kultury. Jak pisze Rakowski, jest to apel o „odzyskiwanie doświadczeń” (2018, s. 18), a także - w moim odczuciu - wołanie o ożywienie ludzi występujących w nieożywionych etnografiach.

W artykule przyglądam się tej interesującej perspektywie, choć, jak zauważa Ryszard Nycz (2018, s. 9), awangardowej i ograniczonej w swoim zasięgu. Poszukuję możliwości zastosowania założeń etnografii przedtekstowej i rozważam, czy zawsze warto przekraczać krytykowane „nachylenie tekstowe”, utożsamiane z epistemologią odziedziczoną głównie po szkole semiotycznej (Clifford 2000, s. 47; Godlewski 2016; 2018, s. 61-66; Hastrup 2018, s. 119). Sięgam przy tym do własnych doświadczeń terenowych wyniesionych $\mathrm{z}$ badań prowadzonych w Zdroju oraz wśród lekarzy podstawowej opieki zdrowotnej (POZ). Ich wyniki kolejno przedstawiam w dalszej części pracy. Sądzę bowiem, że oba projekty badawcze zanurzone są w odrębnych metodologiach i zawierają się w tym, co Grzegorz Godlewski (2016; 2018) określa mianem 
„strategii radaru” i „strategii lunety”. Uważam jednak, że wybór metodologii powinien być pochodną specyfiki samego terenu i badanej grupy. Na tym bowiem polega siła - w tym sensie jeszcze przedtekstowa - antropologii: ma ona unikalną i ugruntowaną zdolność do operowania aparatem otwierającym nowe obszary i tematy, a także stymulującym debatę nad stanem samej dyscypliny. Etnografię przedtekstową pojmuję więc jako apel o powrót do metodologicznych źródeł pozwalających odkrywać ludzi w ich wielowymiarowych aspektach codzienności, a nie projekt wyznaczający nowe drogi poznania.

\section{TEORIA: NACHYLENIE TEKSTOWE I ETNOGRAFIA PRZEDTEKSTOWA}

Sądzę, że spośród dziedzictwa czołowych antropologów drugiej połowy XX wieku to prace Clifforda Geertza wywarły kluczowy wpływ na współczesną antropologię. Odpowiadają za to przemyślenia Geertza, ale także ich krytyka, na bazie której narodziły się refleksyjne, wielogłosowe etnografie i eksperymenty metodologiczne. Jednym z nich jest etnografia przedtekstowa. Punktem wyjścia w refleksji nad etnografią przedtekstową należy więc uczynić kulturę rozumianą jako tekst. W takim znaczeniu tekst jest zespołem wartości, logik i epistemologii, często określanych mianem Teorii Piśmienności (Godlewski 2016, s.63-66; 2018) ${ }^{1}$. Pismo kształtuje naukę - tekst i logika formalna wyznaczają kierunki rozwoju epistemologii i rygory wnioskowania. Dotyczy to także antropologów pracujących w terenie i już poza nim, gdy materiały $\mathrm{w}$ retrospektywnym procesie interpretacji przetwarzane są $\mathrm{w}$ fakty etnograficzne (Ingold 2014, s. 386-389). Te zaś umieszczane są w teoretyczno-pojęciowych matrycach rządzonych zasadami retoryki, logiki i akademickiej estetyki.

Dla antropologii, która bazuje na obserwacji i uczestniczeniu, taka uwaga ma brzemienne skutki. Dochodzimy więc do (kolejnego) paradoksu obserwacji uczestniczącej - to, co badacze postrzegają i w czym uczestniczą, wyrażają poprzez pojęcia i narzędzia tekstowe zniekształcające obraz życia społeczno-kulturowego. Skutki takiej praktyki nie ograniczają się jedynie do usztywnienia obrazu badanego życia. „Nachylenie tekstowe” ma bowiem unicestwiać żywą część kultury, a także nakazuje antropologom spoglądać poprzez tekstowe struktury pojęciowe i logiczne na życie, które pierwotnie nie ma cech tekstu - jest spontaniczne i dzieje się tu i teraz. Wygląda więc na to, że poprzez zanurzenie w kulturze tekstu (a taką jest akademia) łatwo zgubić między słowami sedno etnograficznej sprawy i patrzeć na ludzi tak, jakby byli oni jedynie zapisami-nośnikami kulturowych kodów.

Przewrót refleksyjny sprawił, że wymagania stawiane współczesnej antropologii wykraczają poza tekstowo-interpretatywne schematy. Badacze są świadomi implikacji

${ }^{1}$ Godlewski, pisząc o „nachyleniu tekstowym”, wypowiada się o „kulturze zachodu”. Pomija to, że nie tylko cywilizacja zachodnia wykształciła kulturę opartą na piśmie. Uczyniły to chociażby cywilizacje azjatyckie, w których pismo, a także powiązana z nim logika i schematy pojęciowe odgrywają równie istotną rolę co w „kulturze zachodu”. 
wynikających z „nachylenia tekstowego" i rozumieją, że antropologia musi odpowiadać nowymi propozycjami metodologicznymi na zjawiska zachodzące w świecie. Zatem humanistyka, w tym także antropologia, poszukuje „zmysłu udziału” (Nycz 2018, s. 7-11) opartego na czynnym, głębokim i motorycznym procesie poznawania.

Etnografia przedtekstowa zdaje się spełniać powyższe postulaty, gdyż badacze ją uprawiający poszukują sposobów zanurzenia się w głębszy wymiar rzeczywistości społeczno-kulturowej - sięgają do wrażeń, doświadczeń i bycia-w-świecie. To z nich właśnie czynią źródło wiedzy - doświadczenia zapisane w ciele i pamięci badacza tworzą drogę dochodzenia do wiedzy wyrastającej z notatek terenowych i fragmentów rodzącego się zrozumienia (Rakowski 2018, s. 21-29). Etnografia przedtekstowa to więc specyficzna umiejętność fenomenologiczna oparta na aktywnym i wpisanym w ciało samego badacza procesie, który jest „niepisaną pracą, swoistą historią zrozumienia" (Rakowski, Patzer 2018, s. 2). Oto sedno tak rozumianej etnografii:

[...] narastające i stale aktywne doświadczenie etnograficzne - wiedza przed-tekstowa - nie przynależy do świata intuicji, lecz jest drogą, procedurą, a także aktem objaśniania znaczeń życia społecznego. Ta procedura - czy też rygor budowania wiedzy - tworzy łańcuch z etnograficznych notatek, w tym także z „,headnotes” (Rakowski, Patzer 2018, s. 13)2.

Proces ten nie jest ograniczony jedynie do przebywania w terenie, lecz odbywa się również już po zakończeniu aktu zbierania danych. Badacz nieustannie dokonuje refleksyjnej pracy i aktywnie poszukuje „wydarzeń etnograficznych” (Rakowski 2018, s. 17) - zarówno w terenie, jak i po powrocie, podczas przeglądania notatek terenowych. Wiedzę etnograficzną budują zatem doświadczenia, ulotne ekspresje, opowieści, pamięć, fotografia i film. Można powiedzieć, że etnografia przedtekstowa korzysta ze „zmysłu udziału” - jest wyczulona na docierające do badacza bodźce i doznania kreujące zrozumienie, ale także nie odcina się całkowicie od dziedzictwa szkoły semiotycznej. Przecież wiele z wymienionych elementów to także składowe Geertzowskiego opisu gęstego odsłaniającego pogłębiony i wielowarstwowy charakter wiedzy etnograficznej, powstałej w wyniku zanurzenia w terenie i głębokiej z nim interakcji (Geertz 2005b, s. 47-57). Etnografia przedtekstowa, podobnie jak opis gęsty, jest intelektualnym przedsięwzięciem rozpoznającym drogę dochodzenia do wiedzy i odsłaniającym terenowy detal wyłaniający się z notatek. Obie propozycje traktują kulturę jako kontekst, jako wartką i różnorodną arenę zjawisk społecznych, a teorię antropologiczną jako nieliniowy zbiór wiedzy, odsłaniający - jakby powiedział Geertz (2005a, s. 50) - w poszerzonej perspektywie małe sprawy. Dla Geertza jednakże kultura była manuskryptem zapisanym w nieznanym języku, który można odkodować przez interpretację. Rakowski postuluje zerwanie z taką formą praktyki etnograficznej. Proponuje, aby zastąpiły je

[...] logika działania i udział - odgrywanie, poświęcanie uwagi, podążanie za aktorami i wydarzeniami, który można odnaleźć pod materialnymi, widocznymi danymi. Do takiej wiedzy dochodzi się poprzez rozpoznawanie „wydarzeń etnograficznych” i uczenie się wyczuwania nieustanie

\footnotetext{
2 Tłumaczenie własne autora.
} 
pojawiających się zjawisk w różnych miejscach, w różnych terenach. Stopniowo tworzy się w ten sposób rodzaj milczącego, często niewidocznego, ale intensywnego doświadczenia (Rakowski 2018, s. 17).

Etnografia przedtekstowa jest więc w porównaniu do opisu gęstego „wyczyszczona” (Rakowski 2018, s. 21) i sięga w odmienny sposób do ludzkiego doświadczenia i społecznych interakcji. Słowa, kody i symbole, tak ważne u Geertza, tu są jedynie oczywistościami i gotowymi matrycami wynikającymi z reguł języka, przez które antropologia utraciła kontakt z rzeczywistością. Rakowski pisze:

Sztuka prowadzenia etnografii może więc, poprzez przywracanie znaczenia realnym, ludzkim doświadczeniom burzyć pewną retoryczną magiczność opisów, słów, wyobrażeń i stawać się czymś w rodzaju „sztuki deziluzyjnej” (2018, s. 21).

Taka praca wymaga specyficznej metodycznej atencji, którą opisuje Godlewski (2016; 2018), posiłkując się metaforą „lunety i radaru”. „Luneta i radar” to strategie działania badawczego przeciwstawne w założeniach i celach - do innych danych dotrze badacz korzystający z lunety, gdzie indziej zaś zawędruje ten, kogo prowadzi radar. Strategia lunety, utożsamiana przede wszystkim $\mathrm{z}$ antropologią zanurzoną w paradygmatach i tekstowych regułach poznania naukowego, „kładzie nacisk na udział aktywnych, nawet inwazyjnych narzędzi poznawczych we wszystkich fazach procesu badawczego" (Godlewski 2018, s. 70). Spoglądający przez lunetę antropolog widzi świat przez przyjęty zespół metodologicznych i teoretycznych założeń, które wskazują mu co i jak należy badać w przestrzeni społeczno-kulturowej. Jest to więc systemowa strategia oparta na założeniach charakterystycznych dla „nachylenia tekstowego”.

Strategia radaru to alternatywne podejście, korespondujące z założeniami etnografii przedtekstowej. To postawa, gdzie badacz:

[...] działając jak tradycyjny radar przyjmuje wobec rzeczywistości postawę otwartą: zwraca się jedynie w pewną stronę i wysyła otwarte pytania, jak fale radiowe, gotowy do tego, by odbierać wszystkie nadchodzące sygnały niezależnie od ich charakteru i źródła, w postaciach, w jakich mu się pojawiają (Godlewski 2016, s. 183).

Strategia radaru zakłada zatem otwarcie na nowe i zróżnicowane formy wiedzy opartej przede wszystkim na doświadczeniu i udziale w poznawanej rzeczywistości. Odsuwa rozważania o tym, co ogólne, a co szczegółowe, zastępując je analizą tego, co pierwotne, a co wtórne.

Obraz metodologii antropologii oparty na „lunecie i radarze” nie jest przełomowy. Od dekad środowisko antropologiczne podąża za partnerami w terenie, uczestniczy i wytwarza teorię na podstawie doświadczeń terenowych. Wymaga to także pewnego skupienia na detalu oraz rygoru badawczego, a te, jeżeli przyznać słuszność Godlewskiemu, przynależą raczej do paradygmatycznego świata widzianego przez lunetę, a nie radar. Proponowałbym, aby do opisania idei etnografii przedtekstowej porzucić metafory powiązane $\mathrm{z}$ technologiami optycznymi, a w zamian skupić uwagę na wydawałoby się „pierwotnej” sztuce etnograficznej mobilności i zdolności do aktywnego reagowania na zróżnicowane bodźce pochodzące z terenu. Metodologiczna, 
a w konsekwencji metodyczna plastyczność sprawia bowiem, że antropologia może, jak pisze Kirsten Hastrup (2004, s. 468-470), konstruować swoją epistemologię „jak należy" (getting it right). W ten sposób,

antropolodzy, poprzez pozostawanie w stałym kontakcie z rzeczywistością, a nie dzięki zewnętrznej obserwacji i poszukiwaniu dowodów, mogą robić to, co robią, tak, jak należy to robić [...] (Hastrup 2004, s. 468) $)^{3}$.

Antropolog nie jest zatem skazany na wybieranie między zawężającą lunetą a radarem, który jest przecież kolejnym narzędziem odsłaniającym obiekty - pomijam już jego militarną genezę i szpiegowski kontekst. Dzięki silnemu zwrotowi ku rzeczywistości i poprzez przyjęcie elastycznej strategii poznawczej - w każdej jej postaci i bez odrzucania jej niewygodnych właściwości - antropolodzy rezygnują z usztywniania ontologicznego statusu badanych zjawisk - nie są one wszak dane i odkrywane za pomocą aparatury, a raczej wyłaniają się podczas samej operacji poznawczej, są więc jej konsekwencją i częścią. Uważam więc, że praca przedtekstowa, której sedno widzę właśnie we wspomnianym stałym kontakcie z rzeczywistością, będzie dynamicznym działaniem badawczym opierającym się na sztuce łączenia przynajmniej dwóch tradycji - hermeneutycznej i fenomenologicznej, interpretującej i doświadczającej. Poszukując etnograficznego detalu stanowiącego o sile antropologii nastawionej na interpretację - o czym znakomicie pisali Michael Herzfeld $(1987 ; 2004)$ i Geertz (2005a), obaj doceniający w antropologii umiejętność odsłaniania gęstości ludzkich mikroświatów - możliwe jest poznanie złożone uwarunkowań budujących lokalne epistemologie. Poznajemy zatem w gęsty sposób „lokalne nachylenia”, a także dostrzegamy drzwi, przez które można przeniknąć do mikroświata rozmówców. Jednakże należy również spoglądać poza zawężony, choć detaliczny obraz wyłaniający się z opisu i poszukiwać danych ujawniających kolejne piętra i fenomeny warunkujące lokalną rzeczywistość społeczno-kulturową. Zastosowanie takiej strategii zachęca badacza do wykształcenia „zmysłu udziału”. Należy tu jednak zaznaczyć, że wydawałoby się paradygmatyczna i tekstualna szkoła semiotyczna również faworyzowała głębokie zanurzenie w terenie, czego jasny dowód można znaleźć w klasycznej pracy Geertza Głęboka gra: walki kogutów na Bali (2005b). Tak pojmowana przedtekstowa praca etnograficzna jest więc do pewnego stopnia powtórzeniem Geertzowskiego dziedzictwa, swoistą podróżą między ogółem a szczegółem, między spojrzeniem a odczuciem, między opisem gęstym a logiką udziału. Proces ten nie nosi jeszcze znamion tekstu, jest raczej uważnym rozpoznaniem i częściowym zrozumieniem lokalnego świata. Dlatego sądzę, że epistemologiczne i filozoficzne założenia etnografii przedtekstowej ulokowane są na pograniczu fenomenologii i hermeneutyki. Noszą one znamiona narzędzia jednocześnie objaśniającego i ucieleśniającego badany świat, a przez to sięgają do źródeł semiotycznej i następnie refleksyjnej praktyki etnograficznej, ujawniającej liczne wymiary rzeczywistości społecznej (a także metodologiczne konsekwencje) i interakcji między badaczem a badanymi.

\footnotetext{
3 Tłumaczenie własne autora.
} 


\section{PRAKTYKA}

\section{Zdrój}

Zdrój $^{4}$ to miasteczko o bogatej tradycji uzdrowiskowej położone na południu Polski. Kuracjusze przyjeżdżają tu dla wód, górskiego klimatu, a także kuszeni lokalną ofertą kulturalno-rozrywkową. Do Zdroju przyjechałem w listopadzie 2018 r. z grupą studentek ${ }^{5}$ uczestniczących w zajęciach „Laboratorium: etnograficzne portrety uzdrowisk", prowadzonych w Instytucie Etnologii i Antropologii UW. Celem badania było poznanie sanatoriów-instytucji zdominowanych przez zmedykalizowane praktyki i dyskursy, które, zgodnie z literaturą przedmiotu (Speier 2011; Weisz 2011), miały wywierać wpływ przede wszystkim na kuracjuszy, ale również na społeczność lokalną. Chciałem, abyśmy poznali miejsce, w którym instytucje o bogatej i trudnej historii stykają się z codziennym życiem miasteczka. Taki projekt, w rozumieniu Godlewskiego, należałoby zaliczyć do paradygmatycznych etnografii, ograniczających percepcję badacza. Założyłem bowiem, że sanatoria-instytucje rzeczywiście modelują praktyki i dyskursy obecne w Zdroju i rzeczywiście wywierają nieznany nam jeszcze wpływ na kuracjuszy. Zakładałem, że zbadamy doświadczenia i koncepcje związane ze zdrowiem i chorobą wśród kuracjuszy, którzy, jak uznałem, w sanatorium znajdują się w liminalnym stanie przywracania poczucia dobrostanu psychofizycznego. Przyjąłem, podążając za myślą Arthura Franka (1995) i Lindy Garro (2000), że odbicia tego stanu znajdziemy w narracjach kuracjuszy. W ten sposób pominąłem sam Zdrój jako przestrzeń społeczno-kulturową.

Zdrój zastaliśmy pogrążony we śnie - puste deptaki, gryzący dym z kominów i zimno potęgowały wrażenie nierealności tego miejsca. Początkowo, podzieleni na grupy, szukaliśmy rozmówców w pijalniach, ośrodkach kultury i kawiarniach. Słuchaliśmy ich - czasem razem, czasem każdy z osobna - choć w większości nie byli to kuracjusze, a mieszkańcy Zdroju, którzy nie mieli wiele do powiedzenia o tym, co działo się w sanatoriach. Opowiadali za to o swoim życiu i codzienności.

Podczas pierwszego zebrania nasz zespół ustalił, bazując na wstępnych uwagach uczestniczek grupy, że należy zacząć od rozpoznania lokalnej oferty rozrywkowej, skie-

\footnotetext{
${ }^{4}$ Nazwa miasteczka jest anonimowa. Zdrój znajduje się w jednym z województw na południu Polski i liczy około 10 tysięcy mieszkańców. Miasteczko ma oficjalny status uzdrowiska - w badaniach wykazano lecznicze właściwości występujących tam wód i lokalnego klimatu.

${ }^{5}$ W badaniach udział wzięły: Amanda Falkowska, Joanna Nasiłowska-Rek, Aleksandra Zaborowska, Monika Di Giaccomo-Dziejuch, Małgorzata Łakomska. Zespół przeprowadził 35 rejestrowanych rozmów z mieszkańcami i kuracjuszami, a także szereg nienagrywanych rozmów, opisanych w notatkach terenowych. Podczas badań posłużyliśmy się metodą spaceru etnograficznego, a także uczestniczyliśmy w szeregu czynności i wydarzeniach związanych z życiem codziennym w Zdroju, w tym także w terapiach oferowanych w uzdrowisku. Zespół przeprowadził kwerendę lokalnych zasobów archiwalnych, a także pozyskał zbiory archiwalne - w tym zdjęcia, dokumentu i prace poświęcone Zdrojowi - od rozmówców. Przeprowadziliśmy również ankietę internetową - zebraliśmy 103 odpowiedzi, ponadto sięgnęliśmy po technikę sondy ulicznej. Zgromadziliśmy również bogaty materiał fotograficzny i filmowy. Dziękuję członkiniom zespołu za zaangażowanie i wysoką jakość pracy i zebranych materiałów.
} 
rowanej przede wszystkim do kuracjuszy. Pierwszy wypad nie przyniósł jednak spodziewanych efektów. Wyszliśmy tego dnia razem i niestety nie udało się nam znaleźć miejsca, w którym możliwe było rozpoczęcie prac badawczych przez poszczególne członkinie zespołu. Zniechęceni trafiliśmy do lokalu - nazwijmy go "Sofą” - gdzie, jak się okazało, przychodzili młodzi mieszkańcy Zdroju. Podzieliliśmy się na dwie grupy - jedna przyłączyła się do mężczyzn zajmujących stolik na prawo od baru, druga zaś usiadła w środkowej części sali i przyglądała się występowi lokalnego artysty i jego dość mizernej interakcji z niewielką publicznością. Między mężczyznami a studentkami z pierwszej grupy zawiązała się gęsta interakcja. Dziewczyny, korzystając z okazji, szybko przeszły do pytań ściślej powiązanych z ich zainteresowaniami badawczymi. My zaś - ja i pozostałe członkinie zespołu - przysłuchiwaliśmy się tej rozmowie (i komentowaliśmy ją między sobą), o wiele bardziej interesującej niż występ na estradzie. Dla nas właściwa scena była bowiem w rogu na sofach, a występowali na niej dwudziestoparoletni mężczyźni dość już wyraźnie zmęczeni wieczorem. Wyczuli okazję - pomyślałem zarówno o nich, gdy systematycznie zmniejszali dystans fizyczny dzielący ich od etnografek, jak i o dziewczynach zasypujących ich pytaniami. Nagle rozmowa, dotychczas ogólna i pełna kokieteryjnych zachowań, zmieniła charakter. Mężczyźni sprowokowani pytaniami zaczęli opowiadać o tym, czego nie spodziewałem się usłyszeć - miasteczko, choć rodzinne i ciągle na swój sposób centralne w ich życiach, było dla nich pułapką. Następne czterdzieści pięć minut wypełniły dwie rzeczy: dość rozpaczliwy opis życia w Zdroju i tego, co z nim się wiąże - np. przymusowej migracji zarobkowej czy poczucia podległości i służalczości wobec osób tu przybywających (turystów, inwestorów itp.), a także nachalne już próby przełamania granicy komfortu proksemicznego dziewczyn, którym na szczęście udało się wydostać z opresji. Wykorzystaliśmy moment, kiedy rozmówcy wyszli na balkon zapalić, i opuściliśmy „Sofę”.

Dzięki wnikliwości badaczek i ich zdolności do podążania za terenowymi wydarzeniami w mojej głowie powoli zaczął wyłaniać się nowy obraz Zdroju - zweryfikowany doświadczeniem terenowym - a dzięki temu, jak uznałem, „wydarzeniu etnograficznemu”, był on rewolucyjny. Rzecz jasna nie chodzi o samą wizytę w „Sofie”, która stanowiła tu jedynie pewien kontekst. Sednem spotkania była transmisja wcześniej nieuświadomionej przeze mnie wiedzy o życiu w Zdroju i warunków, w jakich ono się toczy. Grupa oszołomionych używkami i rozczarowanych życiem młodych ludzi uświadomiła mi, że Zdrój to nie tylko pozornie kwitnące uzdrowisko, ale także pułapka, z której co prawda spotkani w „Sofie” ludzie podejmowali próby ucieczki, lecz nieskuteczne - ktoś studiował, ale krótko, ktoś emigrował, ale tylko okresowo. Poznaliśmy więc ludzi, którzy egzystowali w przestrzeni na wpół zdegradowanej, gęstej, bezrobotnej i zadymionej jak zdrojowe powietrze zimą. Byli to młodzi mężczyźni, których życiowe trajektorie nie podążały w sprecyzowanym kierunku i których biografie determinował przyjęty z rezygnacją przypadek.

W rozmowach, które prowadziliśmy w zespole badawczym podczas kolejnych dni w terenie, uznaliśmy, że wizyta w „Sofie” była przełomowym wydarzeniem, wymagającym pogłębionej refleksji rekonstrukcji i interpretacji, a może trafniej - zrozumienia. 
Razem jako zespół, a także indywidualnie, rozpoczęliśmy pracę nad zrozumieniem tego, czego doświadczyliśmy. Podczas rozmów ustaliliśmy, że w „Sofie” uczestniczyliśmy w „wydarzeniu etnograficznym”, które odkryło przed każdym z nas nieuświadomioną wcześniej przestrzeń Zdroju. Nikt z nas nie spodziewał się, że prosperujący kurort może być dla części jego mieszkańców, jak powiedzieli nam rozmówcy, „pułapką". Nie spodziewałem się także, że już na początku badań dane będzie tak wyraźnie to zobaczyć i poznać ludzi, którzy w takiej pułapce żyli. Łączyliśmy detale z indywidualnych notatek i wspomnień z tym, co każdy z nas odczuł, zobaczył i usłyszał w klubie. W ten sposób narodził się zrąb wiedzy już etnograficznej, która stała się wypadkową wspomnień, przeżyć i subiektywnych relacji każdego członka zespołu. Przed etnograficzną wyobraźnią zespołu, a także przed każdą osobą go tworzącą, otworzyła się zupełnie nowa przestrzeń do eksploracji. Podążając więc za terenem i za ludźmi, uznałem, że należy dokonać badawczej reorientacji - z badania uzdrowisk przejść ku badaniom życiowych orientacji, wartości i doświadczeń mieszkańców miasteczka. Okazało się bowiem, że Zdrój, a w szczególności pewna część jego mieszkańców, zmaga się z problemami charakterystycznymi dla Polski posttransformacyjnej - znakomicie tu widocznymi, bo zamkniętymi w niewielkiej przestrzeni społecznej i geograficznej. Przedstawiciele społeczności lokalnej borykają się z takimi problemami jak stan środowiska ${ }^{6}$, bezrobocie czy przymusowa emigracja zarobkowa. Jednakże wiedza zdobyta podczas kolejnych wyjazdów w teren pozwala stwierdzić, że nader wszystko mieszkańcy miasteczka zmagają się ze skutkami przekształceń ekonomicznych, społecznych i politycznych ostatnich dekad, rzutujących na tożsamość tego miejsca, opierającą się głównie na dziedzictwie uzdrowiskowym wykorzystującym lokalne zasoby wód leczniczych. Zdrój, z przestrzeni wypoczynkowo-uzdrowiskowej organizowanej przez państwo i jego instytucje (Węcławowicz-Bilska 2013, s. 304-305) - zarówno w okresie II Rzeczpospolitej, jaki i Polski Ludowej - jak pokazały badania Joanny Nasiłowskiej-Rek i Małgorzaty Łakomskiej, dość gwałtownie znalazł się w przestrzeni na swój sposób już bez-państwa, w kulturze wolnego rynku usług, ekonomii i praktyk nastawionych nie na kuracje, a na turystykę, czego odbicie znaleźć można we fragmentach rozmów:

Jest prywatyzacja. Każdy patrzy na swój nos i buduje sanatoria, nowe domy i tak dalej. Jest mniejsza spójność, mniejsza spójność w gospodarce lokalnej, w inwestycjach lokalnych (w. 6, mężczyzna, około 60 lat).

\section{I kolejny:}

Bolaczką Zdroju jest to, że na przykład brak miejsc pracy w różnych zawodach, dominuje właśnie obsługa sanatoriów, restauracji i tak dalej. Jeśli ktoś ma inne wykształcenie, to trudno mu znaleźć zatrudnienie. Po nas Łemkach, po naszej parafii, najbardziej to widać, do 89 roku wracali ciagle z ziem wygnania, z diaspory. A od 89 jakby ręką odjąt (w. 8, kobieta, około 70 lat).

Taka zmiana, pozornie korzystna dla rozwoju lokalnej przedsiębiorczości, dla wielu okazała się szokiem. Dlaczego? W trakcie kolejnych wyjazdów w teren człon-

${ }^{6}$ Jakość powietrza w polskich uzdrowiskach była komentowana w prasie: https://forsal.pl/artykuly/1409446,kurorty-w-smogu-w-uzdrowiskach-brakuje-swiezego-powietrza.html (dostęp 23.03.2020). 
kinie zespołu i ja także zebraliśmy dane sugerujące, że pamięć społeczno-kulturowa w Zdroju mocno jest zakorzeniona w opowieściach i dyskursach narastających wokół tradycji uzdrowiskowej opartej na wodzie, lokalnym zasobie-aktorze, któremu przypisywane są właściwości wykraczające poza jedynie leczniczy wymiar. Tradycja ta sięga jeszcze końca XIX wieku i międzywojnia, a więc czasów, kiedy narodziła się nowoczesna forma Zdroju, ukształtowana przez upaństwowioną ideologię modernizmu i higieny (Kulak, Czapliński 1992, s. 280-285; Szmitkowska 2018, s. 84-89; Wiśniewski 2013, s. 311-320). Pamiątki z tego okresu to głównie zabytki architektoniczne zbadane przez Aleksandrę Zaborowską - wille, łazienki, pijalnie wód, ale także organizacja przestrzenna miasta ciągle odzwierciedlająca panujące niegdyś w Zdroju stosunki klasowe. Swoisty „kult” wody i elitarności przywoływane były podczas ważniejszych wydarzeń w miasteczku, a także dzięki inicjatywom pasjonatów tego miejsca. W tak niewielkiej społeczności działania te przynosiły wymierny efekt - każdy w zasadzie wiedział, jaki Zdrój był niegdyś wspaniały, każdy w zasadzie wiedział też, że do dziś jest „perłą polskich uzdrowisk”.

Zatem Zdrój to ciągle miejsce, w którym woda, powiązane z nią znaczenia i jej przepływy organizują przestrzeń społeczną i kulturową. Woda zdrojowa to lokalne dziedzictwo, a także czynnik kulturotwórczy. Dzięki niej działają sanatoria i przyjeżdżają kuracjusze. Lokalny zakład produkujący wodę na eksport (jedyny większy zakład przemysłowy w mieście) zapewnia miejsca pracy, woda jest również podstawą rozwoju ruchu turystycznego i reklamą miasta. Każda z badaczek wielokrotnie słyszała od rozmówców, iż w Zdroju istnieje cały „przemysł wodny”, a sama woda, jak pokazały badania Moniki Di Giacomo-Dziejuch, jest obiektem-podmiotem szczególnej wagi i uwagi, któremu przypisuje się mnogość znaczeń. Ma ona moc sprawczą: woda leczy, woda daje i zabiera pracę, złoża wody ograniczają możliwość wznoszenia budynków, woda zachęca do działania i przedsiębiorczości lub wręcz przeciwnie - tłumi inicjatywę i zamyka społeczność lokalną w uzdrowiskowym skansenie. Woda w Zdroju to zatem coś więcej niż społecznie niema substancja - jest, jak zauważa Matthew Gandy (2013) w rozprawie poświęconej wodnej infrastrukturze miast, „łącznikiem i koordynantem”. Zbliżam się więc do rozumienia miasta Zdroju, tak jak robili to urbaniści utożsamiani z tzw. ruchem organicznym (Gandy 2013, s. 340-342; Sennett 2015) - widzę Zdrój jako swoisty organizm, który tworzą elementy tkanki społecznej i miejskiej połączone uzdrowiskową infrastrukturą. Woda w Zdroju to swoista "krew” miasteczka, a instytucje z nią powiązane tworzą jego krwiobieg, którym wędrują idee, wartości, pamięć i praktyki.

Wróćmy do uzdrowiskowych korzeni Zdroju, by lepiej ukazać, jak woda była i jest ważna w Zdroju. Miasto rozwinęło się dzięki nowym dyskursom higienicznym popularnym na przełomie XIX i XX wieku w niemalże całej Europie (Blackbourn 2002; Steward 2002). Powstało jako alternatywa wobec metropolii uważanych za brudne i chorobotwórcze, było miejscem ucieczki elit „do wód” po zdrowie. Gandy (2013, s. 343-350) określa takie uzdrawiające miejsca mianem „miast bakteriologicznych", gdzie idee postępu medycznego, technologicznego, prawnego i ogólnospołecznego materializowały się pod postacią architektury, kompozycji przestrzennej 
i nowego porządku społecznego. Nowoczesne oblicze Zdroju ufundowane zostało na tych właśnie wielkich opowieściach, tworzących nowe funkcje miasta i nowe role powiązanych z nim grup społecznych. Woda i rozwój infrastruktury uzdrowiskowej miały tu kluczowe znaczenie, podobnie jak mechanizmy władzy oraz instytucjonalne reżimy oparte na kulturze elitarnej i biomedycznej, odbijające się w architekturze i relacjach społecznych. Miejscem, gdzie w Zdroju te dyskursy materializowały się pod postacią elitarnych praktyk i norm - jeszcze w czasach pozornie antyelitarnego PRL-u - były sanatoria, łazienki i pijalnie. Również deptak, w Zdroju długo rządzący się pewną etykietą, był przestrzenią zarezerwowaną dla elit. Niektórzy z rozmówców ciągle pamiętali te czasy:

To byly czasy takie dziwne, gdzie tu, $w$ rejon deptaku, $w$ ciagu dnia pracownik $w$ stroju roboczym nie miał wstępu. To było dla gości, tu nie można było prowadzić żadnych prac od mniej więcej dziewiątej rano do osiemnastej (w. 11, mężczyzna, około 70 lat).

I podobna wypowiedź:

Mogli być tacy odźwierni czy coś, którzy ludzi źle ubranych nie wpuszczali w to ścisłe centrum tutaj - to było takie elitarne, tutaj powiedzmy. Trzeba już być ubranym było, chłop w gumiakach na przykład, nie, to nie uchodziło w tym momencie. A w ogóle chyba była taka ulica graniczna, $z$ tego co slyszałem, nie znam dokładnie tej historii, że tam tylko do tej ulicy można było wozami podjeżdżać, wóz konny nie typu dorożką, tylko który tam dostarczał jakieś produkty (w. 14, mężczyzna, około 70 lat).

Małgorzata Łakomska wykazała, że po wojnie Zdrój utrzymał stricte uzdrowiskową funkcję, nastąpiły jednak wyraźne zmiany w strukturze osób przyjeżdżających do miasteczka. Do kontrolowanych przez państwo i rozbudowywanych sanatoriów przybywali przede wszystkim przedstawiciele klasy pracującej, choć nie tylko - w Zdroju kurację odbywali także funkcjonariusze państwa, w tym wojskowi i przedstawiciele milicji, jak również przedstawiciele szeroko rozumianej „inteligencji”. Wyburzono wiele zabytkowych („burżuazyjnych”) willi, a zastąpiła je monumentalna architektura sanatoryjna charakterystyczna dla Polski Ludowej (Cymer 2013, s. 319-323). Zdrój częściowo zatracił swoją elitarność - zapanowała w nim zideologizowana i upaństwowiona praktyka i myśl uzdrowiskowa wpisująca się w nurt działań Polskiej Rzeczpospolitej Ludowej kwestionujących pozycję przedwojennych elit. Pamięć o dawnej etykiecie tego miejsca jednakże nie umarła.

Transformacja ustrojowa przyniosła do Zdroju liczne zmiany, zarówno w relacjach społecznych, jak i w architekturze. Wraz z wycofaniem się państwa i jego instytucji z nadzoru nad zasobami uzdrowiskowymi w Zdroju pojawiły się kapitalistyczne modele zarządzania i przedsiębiorczości. Sanatoria, podobnie jak ośrodki hotelowe i wypoczynkowe, przeszły w prywatne ręce lub do różnych spółek funkcjonujących na zasadach rynkowych. Rozproszeniu uległ zatem monolityczny model zarządzania lokalnymi zasobami dobrami, w tym wodą, która, jak pokazały badania Moniki Di Giaccomo-Dziejuch i Joanny Nasiłowskiej-Rek, z dobra wspólnego przynależącego do Zdroju i jego mieszkańców stała się zasobem sprywatyzowanym i oddanym w ręce nowych aktorów społecznych. W Zdroju pojawili się zatem nieznani wcześniej gracze, 
którzy z lokalnych dóbr, w tym wody i przynależnej do niej infrastruktury, uczynili źródło zysku ekonomicznego, a nie społecznego. Przykładem może być masowy eksport butelkowanej wody leczniczej - zjawisko przez wielu naszych rozmówców krytykowane, a przez niektórych wręcz utożsamiane z zalegalizowaną grabieżą i szkodliwą eksploatacją źródeł. Zdrój przyciągnął nowych ludzi, przedstawicieli rodzącej się klasy średniej, właścicieli i przedsiębiorców inwestujących w nieruchomości - a w wymiarze lokalnym przejmujących je w niejasnych okolicznościach. Od początku swojej obecności w miasteczku patrzyli oni na wodę oraz miejscowy klimat nie jak mieszkańcy Zdroju, dla których są one symbolami, dobrem publicznym i filarami tożsamości tego miejsca, ale jak biznesmeni, dla których zdrojowe walory to towar. Trzy dekady prywatyzacji doprowadziły do erozji więzi pomiędzy lokalną infrastrukturą uzdrowiskową a domeną publiczną. Nie obowiązują już, jak pokazała Aleksandra Zaborowska, historyczne związki pomiędzy estetyką, lokalnymi zasobami a przestrzenią miejską. Ta bowiem została „połamana” nowymi i nierzadko kontrowersyjnymi inwestycjami, chaotycznymi szyldami, wzmożonym ruchem samochodowym i rozwojem infrastruktury typowo turystycznej, za który odpowiadały osoby niezwiązane wcześniej z tym miejscem. Miejska sensosfera, w tym jej warstwa wizualna i akustyczna (hałas generowany przez ruch ciężarowy stał się uciążliwy), jak przekonują badania Amandy Falkowskiej, uległa więc daleko posuniętej dekompozycji, a także swoistej makdonaldyzacji. Jak powiedział jeden z naszych rozmówców: Ja pamiętam Zdrój, który był piękny. W tej chwili jest spaskudzony (w. 12, mężczyzna, wiek nieznany).

Uważam, że w tej wypowiedzi „piękny” należy rozumieć jako przedkapitalistyczny, to jest taki, w którym państwo organizowało i dbało o lokalną przestrzeń pełniącą funkcje niemal wyłącznie uzdrowiskowe. Choć estetyka okresu PRL-u może budzić zastrzeżenia, jak przekonują Łakomska i Zaborowska, ciągle jednak była powiązana z historyczną funkcją miasta - gmachy w podobnym stylu wznoszono dla kuracjuszy, choć należy przyznać, że często robiono to bez poszanowania lokalnych walorów krajobrazowych i architektonicznych. Nie zmienia to jednak faktu, że w świadomości rozmówców Zdrój był wówczas ciągle dumnym uzdrowiskiem, a państwo dbało o to, aby funkcjonowało ono na przyzwoitym poziomie, także jeśli chodzi o ofertę kulturalną. W ogóle należy zauważyć, że organizacja oferty kulturalnej w uzdrowiskach PRL-u - niekiedy stojącej na dobrym poziomie - wciąż była częścią myśli modernizacyjnej realizowanej przez państwo. Oto bowiem klasa pracująca w wolnym czasie miała szansę obcować z teatrem, muzyką i innymi sztukami. Współcześnie w Zdroju oferta kulturalna - nie licząc kilku wciąż tu obecnych cyklicznych festiwali - jest stosunkowo uboga (szczególnie poza sezonem letnim), można powiedzieć, że przeżywa kryzys. Świadczy o tym chociażby historia Orkiestry Zdrojowej grającej nieprzerwanie od międzywojnia. Współczesna orkiestra występuje w poważnie okrojonym składzie (na skutek cięć budżetowych), co ogranicza jej możliwości artystyczne. W pewnym momencie - w trakcie naszych badań - Orkiestra, na skutek konfliktu z władzami spółki zarządzającej uzdrowiskiem, straciła nawet prawo do koncertowania w Pijalni Głównej. Wielu mieszkańców Zdroju odebrało to jako upadek wieloletniej tradycji uzdrowiska. 
W Zdroju dokonała się zatem transformacja z miasta bakteriologicznego ku miastu antybiologicznemu i kapitalistycznemu (Gandy 2013, s. 351-360), zdominowanemu przez turystykę oraz ekonomię wolnorynkową, w praktyce zmuszając mieszkańców do szeroko pojętej obsługi przyjeżdżających tu ludzi, w tym także kupujących nieruchomości. To oni bowiem - jak przekonywali rozgoryczeni rozmówcy - stają się nowymi „właścicielami” Zdroju. Zdrój cieszy się statusem uzdrowiska, co oznacza, że w mieście nie mogą rozwijać się sektory generujące lepiej płatne miejsca pracy. Mamy więc do czynienia z przestrzenią częściowo przemienioną w turystyczny i ciągle jeszcze uzdrowiskowy „rezerwat”, wykluczający, kosztowny i aspirujący do miana elitarnego. W takiej przestrzeni ludzie spotkani w „Sofie” (ale nie tylko oni, co pokazały badania) nie potrafili się odnaleźć. Była ona dla nich obca, choć tu się wychowali, zamknięta, gdyż nie mieli wstępu na lokalne „salony”, i wreszcie niezrozumiała, gdyż brakowało im kapitału społecznego i ekonomicznego - mapy, dzięki której mogliby poruszać się w urynkowionej przestrzeni Zdroju. Dla nich woda, historia Zdroju, rynek turystyczny i górski klimat tworzą sieć, która ogranicza biograficzne trajektorie i zabiera możliwość wyglądania w przyszłość. Elementy te razem wzięte tworzą ucieleśnioną barierę oraz są niekiedy źródłem kontestowania lokalności i wyrażania pogardy. Rozmówcy z „Sofy” przyznali, że nie cenią - jak inni - lokalnych wód i sanatoriów, oszukiwali turystów na pieniądzach, nie żywili też sympatii do nowych mieszkańców Zdroju, którzy inwestowali („zabierali”) w nieruchomości, zmuszając rodowitych mieszkańców do emigracji lub wyprowadzania się do gorzej położonych mieszkań.

Zatem, dzięki jednemu spotkaniu oraz zmianom celu i metodologii badań, staliśmy się jako zespół badawczy, a zarazem każdy z nas z osobna, świadkami żywych podziałów społecznych, odbijających się na życiowych orientacjach mieszkańców Zdroju, ich biografiach, a wreszcie na relacjach z miejscem zamieszkania, jego historią i lokalnymi zasobami przyrodniczymi. Nie byłoby to jednak możliwe, gdyby nie metodologiczna i metodyczna refleksyjność oraz plastyczność, leżące u podstaw współczesnej antropologii. To właśnie tę zdolność do refleksji i zmiany, a w zasadzie naturalnej „ewolucji” (antropolodzy wydają się uczuleni na ten termin, lecz ewolucja to przecież niezorientowany i nieliniowy proces zmian w czasie) terenowych orientacji badacza, traktuję jako podstawę i sedno działań jeszcze przedtekstowych. Ta plastyczność, a więc niezapisana „na sztywno” ścieżka ku zrozumieniu, zapewnia stały kontakt z rzeczywistością, a w konsekwencji z wyłaniającymi się zjawiskami i usłyszanymi historiami, którym badacz nie nadaje sztywnego statusu ontologicznego.

\section{PODSTAWOWA OPIEKA ZDROWOTNA}

Badania nad podstawową opieką zdrowotną ${ }^{7}$ różnią się od tych w Zdroju. Przyznaję, że są one metodologicznie bardziej usztywnione, przez co pozornie przypominają spoglądanie przez lunetę na wycinek rzeczywistości. Materiały stanowiły

${ }^{7}$ Indywidualny projekt badawczy prowadzony w latach 2014-2018. Więcej o szczegółach projektu i wynikach badań zob. w Wierciński 2016; 2017; 2019; 2020. 
przede wszystkim wywiady z lekarzami. Obserwacje ich pracy ograniczają się jedynie do dwóch przychodni, gdzie umożliwiono mi (za zgodą pacjentów) przyglądanie się niektórym działaniom lekarzy w gabinetach, a także dłuższe przebywanie na terenie przychodni, gdzie również prowadziłem obserwacje, choć nieuczestniczące. Przyglądałem się spontanicznym interakcjom pomiędzy lekarzami i pacjentami, czasem iskrzącym, czasem pełnym troski i uwagi. Wiele z tych interakcji wykraczało poza zmedykalizowane schematy i przypominało mi, że także w przestrzeniach przychodni toczy się życie oparte na przykład na relacjach wymiany, gdzie w obiegu były przedmioty użytkowe, jedzenie, leki, a także nieformalne usługi wytwarzające złożone interakcje społeczne.

Nieco lepiej wykorzystałem przybornik etnograficzny na spotkaniach Porozumienia Zielonogórskiego, organizacji zrzeszającej lekarzy pracodawców. Zostałem tam zaproszony przez dwójkę lekarzy, dzięki czemu mogłem przyglądać się, jak w cyklicznym „rytuale zebrania” członków tej organizacji tworzy się - przede wszystkim przez wymianę i konstruowanie treści, poglądów, wartości i doświadczeń związanych z codzienną pracą - tożsamość zawodowa lekarzy-przedsiębiorców zmagających się z postępującą biurokratyzacją ich zawodu, niekorzystnymi reformami i problemami wynikającymi z ogólnej organizacji polskiej opieki medycznej. Godlewski najpewniej nie zgodziłby się ze mną, ale obraz POZ, jaki otrzymałem po czterech latach badań, uważam w pewnym stopniu również za rezultat przedtekstowej refleksji, opartej jednak na innych przesłankach niż w Zdroju. Poprzez koncentrację na gęstym i detalicznym wymiarze badanego świata chciałem zrozumieć, jakie dominują w nim treści, praktyki i wartości. Chciałem także przez ich poznanie zrozumieć, jak mogę dostać się do interesującej mnie rzeczywistości lekarzy. Drzwi polskich placówek medycznych nie są bowiem otwarte dla etnografów chcących prowadzić tam badania. Można się o tym z łatwością przekonać, podejmując próby zbadania środowiska lekarzy - elitarnej, hermetycznej i „racjonalnej” kultury profesjonalnej (Hahn, Kleinman 1983; Rhodes 1996), w której kluczową rolę odgrywają usystematyzowane i weryfikowane fakty naukowe konstytuujące zrąb wiedzy o człowieku. Osoby mające taką wiedzę, a także potrafiące dzięki swemu wykształceniu i doświadczeniu zamieniać ją w praktyczne działania - np. w leczenie lub prowadzenie badań naukowych - w tej kulturze uchodzą za swoistą elitę nie tylko społeczną, ale również intelektualną. Mowa zatem o kulturze, której „nachylenie tekstowe" jest dystynktywną cechą i wartością samą w sobie. Przekonałem się o tym w terenie, spotykając lekarzy, którzy oczekiwali ode mnie realizowania badania opartego na zestandaryzowanym oraz (ich zdaniem) „obiektywnym” kwestionariuszu i precyzyjnie opisanym aparacie teoretyczno-pojęciowym - a więc chcieli mnie oni widzieć $\mathrm{z}$ lunetą $\mathrm{w}$ ręku. Wszelkie inne - ich zdaniem nienaukowe - modele deprecjonowali, a spotkania ze mną nie traktowali jako poważnej wymiany wiedzy, myśli oraz doświadczeń. Bez odpowiedniego „nachylenia tekstowego” niezmiernie trudno było mi dostać się do kultury opartej tak wyraźnie na logicznych reżimach charakterystycznych dla nauk przyrodniczych. Kultura profesjonalna lekarzy to kultura silnie zmedykalizowana. 
Moje nachylenie przejawiało się przede wszystkim w przyjętej strategii, która - powtórzę to - wynikała z uważnej analizy specyfiki badanej grupy i terenu. Analiza ta oparta była na wiedzy i doświadczeniach wyniesionych z wcześniejszych badań, a także stanowiła efekt badania pilotażowego - powiedzmy radaru, dzięki któremu ujrzałem obrys badanego świata. Przyznaję jednak, że projekt badań w POZ przypomina raczej posługiwanie się narzędziem optycznym, a nie waloryzowanym przez Godlewskiego korzystaniem z radaru. Oparty był na krótkich, ale licznych wyjazdach w teren, a same badania realizowałem wedle luźnego kwestionariusza pytań skoncentrowanych wokół kluczowych problemów. Są to kolejno: reformy w opiece medycznej, przychodnia POZ rozumiana jako przedsiębiorstwo, społeczna rola lekarzy POZ oraz doświadczenia transformacji społecznej, ekonomicznej i politycznej w opiece medycznej. Ramę dla tak zorientowanych badań, obok refleksji nad kulturą profesjonalną lekarzy, stanowią także studia nad postsocjalizmem. Myślę tu o rozpoznaniu propozycji teoretyczno-metodologicznych dla badań nad postsocjologicznymi systemami opieki medycznej (Speier, Šmídová, Wierciński 2014, s. 815-816), a także o transformacji kultury pracy w warunkach gospodarki kapitalistycznej (Dunn 2008a; 2008b). Moja uwaga koncentrowała się także na nowych tożsamościach uczestników, które bez wątpienia wykrystalizowały się w atmosferze sukcesu związanego z kulturą wolnego rynku (Vonderau 2008). Pojęciowo-teoretyczne ramy i metodologie służą mi jednak nie do umieszczenia badania w ograniczonym paradygmatycznie schemacie, a raczej jako klucz dostępu do badanego środowiska i jego kultury. Podążam zatem za myślą Michaela Herzfelda, doskonale ujętą w tych słowach:

Ja sam odniosłem wrażenie, że pożyteczne jest myślenie w kategoriach rozróżnienia pomiędzy opartymi na języku i wywiedzionymi z języka modelami znaczenia (Herzfeld 2004, s. 87).

Tylko właśnie pewien specyficzny język-tekst, za którym kryją się poddane racjonalizacji wartości i reżimy wiedzy, był dla mnie dostępny w środowisku lekarskim. Na podstawie wyników wieloletnich badań nad opieką medyczną sądzę, że to tekst jest dla członków tej kultury podstawową osią, wokół której rodzą się ich doświadczenia i osobiste refleksje. Tekst rozumiany jako zmedykalizowane modus operandi był tu także punktem odniesienia, nawet gdy lekarze wychodzili poza „racjonalne” i zmedykalizowane ramy pojęciowe i przechodzili do logik nieformalnych relacji. Przejście to jest doświadczeniem wyjścia z tekstualnej przestrzeni w kierunku tej spontanicznej i przygodnej i mogę stwierdzić, że tak właśnie było interpretowane przez rozmówców - jako wycieczka na drugą stronę, jednakże ze świadomością, iż jest to wypad na marginesie ich głównej działalności. Nachylam się więc celowo i oglądam w powiększeniu dostępne mi narracje i praktyki, co daje pewne wyobrażenie o lekarskim świecie, o panujących tam regułach i doświadczeniach ujętych w swoistą opowieść o medycynie, o praktyce, o wiedzy. Tekstualna wiedza to bowiem właśnie ich świat i narzędzie do jego interpretowania. Teksty i zawarta w niech wiedza pozwalają lekarzom (czasem dosłownie) operować w świecie i go aktywnie zmieniać. 
Dystynktywną cechą lekarskiego świata jest jego logiczność i elitarność wyrażana przez etos kultury profesjonalnej odwołującej się do wielkich pozytywistycznych i modernistycznych opowieści „uwalniających” człowieka - dzięki sile rozumu i logice - od przygodności przyrody. Kultura biomedyczna oparta jest więc na racjonalnościach, które Eliane Riska i Aurelija Novelskaite (2011) określają mianem „logik” - przestrzeni, gdzie kształtują się środowiskowe wartości i dyskursy przekładające się na działania lekarzy. Obok logiki „nieformalnej ekonomii” i „rynku” dwie przestrzenie - „państwo” i „kultura profesjonalna” - wydają się dominować. To one bowiem nadają kulturze biomedycznej wyraźnie tekstowego charakteru, opartego na logice, wiedzy i specyficznie rozumianej racjonalności, co pozwala mi stwierdzić, iż świat lekarzy tak się ma do świata pacjentów, jak klasyczny w antropologii medycznej podział na disease i illness, gdzie pierwszy termin oddaje zmedykalizowany obraz zjawiska, a drugi opisuje przestrzeń subiektywnych doświadczeń choroby (Fabrega 1980; Fabrega, Silver 1973). Świat lekarzy wydaje się więc przede wszystkim „racjonalny” i zorganizowany wedle wartości wyniesionych jeszcze z okresu edukacji opartej na reżimie wyczerpującego uczenia się, na cyklicznych próbach wytrzymałości psychicznej (i fizycznej) oraz na logice nauk przyrodniczych. Także ich miejsca pracy - mój „teren” - nierzadko dyskryminujące ze względu na płeć lub wiek ${ }^{8}$, hierarchiczne oraz wymagające podejmowania szybkich i trafnych decyzji, wymuszają na lekarzach działania oparte na wyuczonych i logicznych schematach - choć nie odbywa się to bez ponoszenia kosztów osobistych:

Praca $w$ szpitalu wyglądała koszmarnie. Na oddziale było 82 pacjentów i pacjenci leżeli też oczywiście na korytarzu. Na dyżurze, którym ja brałam z koleżanką, musiałyśmy zrobić obchód. I niech pan policzy, 82 razy 5 minut dla każdego pacjenta, ile to jest. W związu z tym przelatywaliśmy przez sale dosłownie jak śmigła (w. 5, kobieta, 45 lat).

Rozmówczyni, ze względu na trudne warunki panujące w szpitalu, zdecydowała się zmienić pracę i obecnie pracuje jako lekarz kontraktowy w kilku przychodniach POZ w Warszawie. Jednak, choć tempo pracy wydaje się wolniejsze, a poziom swobody działania wyższy niż w szpitalu, POZ nie jest wolna od zawodowych trudności, o czym przekonuje kolejna rozmówczyni:

Stres jest ogromny. Z tym, że w szpitalach te decyzje wszystkie odnośnie procesu leczenia sa podejmowane w pewnych zespołach i zawsze moga na jakimś etapie być skontrolowane przez innego kolege czy koleżankę. No a tu jest człowiek sam odpowiedzialny za swoje decyzje i to jest na pewno stresem dużym. Jest się tylko samym w gabinecie, a trzeba jakaś decyzję podjać. Taka jest to przede wszystkim odpowiedzialność (w. 17, kobieta, około 60 lat).

Lekarze są więc też zwykłymi ludźmi - stresują się, rządzą nimi namiętności, pasje, czasem działają niekonsekwentnie albo dają się ponieść logice „nieformalnej ekonomii” - nie chodzi tu o praktyki korupcyjne, a o mnogość interakcji pomiędzy nimi

${ }^{8}$ Niektóre specjalizacje, takie jak chirurgia, ciągle zdominowane są przez mężczyzn i uważane za męskie. Najmłodsi lekarze-rezydenci także doświadczają dyskryminacji ze względu na wiek i swój status lekarzy ciągle się uczących. 
a pacjentami, które nie mieszczą się w biomedycznym modelu (Farmer, Kilpatrick 2009; Kilpatrick et al. 2009). Na podstawie zebranego materiału mogę stwierdzić, że takie niemedyczne relacje w medycznym świecie nie są rzadkością, choć należy podkreślić, iż częściej dostrzegałem je w niewielkich przychodniach zlokalizowanych w obszarach wiejskich lub małomiejskich. Gabinety POZ przejęły tam społeczną rolę dawnych przychodni rejonowych i pełnią funkcję poradni nie tylko medycznych, ale też „osobistych”. W wielkomiejskim środowisku pogłębione relacje pomiędzy lekarzami i pacjentami były raczej rzadkością. Rotacja pacjentów przemieszczających się między prywatną opieką a tą zapewnianą przez państwo, a także mobilność lekarzy, który niechętnie decydowali się na pracę w jednym miejscu (ze względów ekonomicznych i tożsamościowych - wybór miejsca pracy utożsamiano z wolnością zawodową), powodowały, że obserwowane relacje przypominały te oparte na niemalże klienckiej regule - jest zapotrzebowanie, a więc jest i instytucjonalnie rozumiane „świadczenie”.

Zatem obraz przestrzeni zawodowej lekarzy jawi mi się tak: jest pozornie spójny, unaukowiony, brakuje w nim miejsca na nielogiczności i przygodność, brak mu też cech żywej kultury. Jest na swój sposób sztuczny. Za taki stan odpowiada jego silnie tekstowy charakter, a także nabywane przez medyków wyobrażenia i definicje na temat profesjonalności, autorytetu i elitarności tego zawodu (Carrese, Marshall 2000). Lekarze są przede wszystkim działającymi „umysłami”, ich niepewności, cielesność oraz emocjonalność, zgodnie z profesjonalnym kanonem, muszą zostać stłumione i usunięte z życia zawodowego. Słyszałem jednak, że zdarzały się rozmówcom chwile zawahania lub też potrzeby zasięgnięcia porady u kolegi/koleżanki. Nie były one jednak przesadnie eksponowane, choć nie mogę także jednoznacznie stwierdzić, że lekarze ukrywali swoje słabości. Być może wynika to z tego, iż POZ, ze względu na wyraźniejsze i długotrwałe zanurzenie w społeczności lokalnej i jej sprawach, rządzi się bardziej - można powiedzieć - miękkimi, to jest „ludzkimi” prawami. Jest to szczególnie widoczne, gdy porówna się podstawową opiekę, która w założeniu ma pewien rodzaj prospołecznej misji (stała opieka, pogłębiona znajomość, pogłębiony i rozciągnięty $\mathrm{w}$ czasie kontakt $\mathrm{z}$ pacjentami, a nierzadko też $\mathrm{z}$ ich zapleczem społecznym - z rodziną, sąsiedztwem itp.) do sektora opieki opartej niemal wyłącznie na zasadach charakterystycznych dla „twardej” i silnie redukcjonistycznej EBM (evidence based medicine), odwołującej się do jedynie naukowo potwierdzonej wiedzy przekształcanej na kliniczną praktykę (Sackett 1997, s. 3).

Wpływ na postawy lekarzy wywierają również nadrzędne wobec nich instytucje państwowe, które regulują - przez ustawy, kontrakty oraz inne dokumenty - kto może być lekarzem, w jakim zakresie może działać i jaką ponosi odpowiedzialność. Etos i wartości lekarzy kształtują także instytucje działające w obrębie kultury biomedycznej, takie jak akademia, kolegia i gremia zrzeszające autorytety (Good 1994). Posługują się one nierzadko totalizującymi opowieściami o misji i celu medycyny w odkrywaniu zobiektywizowanej „prawdy”. Takie opowieści słyszałem między innymi podczas różnych zgromadzeń lekarzy (konferencji, sympozjów itp.), ale również podczas zebrań Porozumienia Zielonogórskiego, także przecież instytucji politycznej, od początku swojego istnienia zanurzonej w stricte wolnorynkowym środowisku społecznym. 
Zatem dyskurs aparatu instytucjonalno-administracyjnego, obok wewnątrzśrodowiskowego etosu i logiki nauk przyrodniczych, to najważniejsze tekstowe „zapory”, przez które musi przedrzeć się / które musi zrozumieć etnograf, by dostać się do świata lekarskiego. A ten, po wielu latach badań, choć pozornie uregulowany, jawi mi się jako pełen napięć wynikających z kolizji pomiędzy poszczególnymi „logikami” niemożliwymi do zespolenia w konsekwentną całość. Lekarzom, szczególnie w prospołecznej POZ, gdzie ideą i wartością jest poznanie pacjenta oraz współpraca z nim rozłożona w czasie, trudno zaakceptować instytucjonalne reżimy oraz zakresy dostępnych procedur medycznych, zawężane w kontraktach podpisywanych z Narodowym Funduszem Zdrowia9. Trudno im także pogodzić prospołeczną misję wpisaną w ideę podstawowej opieki zdrowotnej z rynkowym charakterem prowadzenia przychodni, które, jak określiła jedna z rozmówczyń, są „przedsiębiorstwem, społecznym, ale jednak przedsiębiorstwem”. Lekarzy POZ, obok profesjonalnej logiki, charakteryzuje zatem także doza osobistej i środowiskowej niepewności wynikającej z konieczności odgrywania wielu niespójnych ról. Jak bowiem pogodzić pracę lekarza z działaniem na rzecz społeczności lokalnej, profilaktykę wymagającą czasu i uwagi oraz uważne śledzenie losów pacjentów, ze sztywnymi zapisami w kontrakcie z NFZ? Lekarze zadają sobie pytania o to, jak radzić sobie z instytucjonalnymi rygorami, za złamanie których grożą kary pieniężne, jak postępować z opresyjną biurokracją i jak wykonywać obowiązki, bilansując przy tym wydatki i przychody swoich firm-przychodni?

Te pytania oraz wynikające $\mathrm{z}$ nich niespójności i obawy były czytelne w dostępnych narracjach, które postrzegam jako zniekształcone, lecz ciągle refleksyjne sprawozdania z żywych doświadczeń (Garro 2000). Są one ułożone wedle lokalnego kanonu, który, choć między wierszami traktuje o żywym doświadczeniu i pojawiających się w nich nieciągłościach, ciągle jest profesjonalny i silnie zmedykalizowany. Choć próby odczytania go kierują mnie wyraźnie ku szkole semiotycznej, rozpoznanie zawartych w nim znaczeń było możliwe - jak sądzę - dzięki zastosowaniu specyficznie pojętej idei etnografii przedtekstowej. Mowa tu przede wszystkim o rekonstruowaniu ścieżki etnograficznego poznania poprzez intensywną analizę notatek oraz innych ucieleśnionych wrażeń i doświadczeń terenowych. Myślę tu także o stałym i uważnym przyglądaniu się terenowi i panującym w nim warunkom. Podjąłem aktywną - radarową - próbę podążania za terenem, za wskazówkami, które płynęły do mnie ze strony środowiska lekarskiego, za kolejno rozpoznawanymi cechami kultury tego środowiska, które - nim jeszcze zamieniłem obserwacje w jakąś formę tekstu - uznałem za obrys zjawisk kluczowych dla mojego dociekania. Te praktyki badawcze, balansujące między interpretacją a próbą głębszego udziału w rzeczywistości, można uznać za jeszcze wolne od tekstualizacji. Jednakże, bez usztywniającej konkretyzacji projektu (nie zakładam przy tym, że etnografia przedtekstowa jest niekonkretna) i ujęciu go w paradygmatyczne ramy metodologiczno-teoretyczne (które zawężają obraz

\footnotetext{
${ }^{9}$ Kontrakt precyzyjnie reguluje, jakie świadczenia płatnik (NFZ) zamawia i za jakie płaci. Nieprzestrzeganie zapisów kontraktu grozi karą finansową lub nawet jego zerwaniem.
} 
widzenia), jego realizacja byłaby niemożliwa. Takie warunki bowiem narzucił mi sam teren i spotkani w nim ludzie, tego wymagała ode mnie zastana kultura lekarska, to pokazał mi radar raportujący o istnieniu lokalnych i specyficznych dla praktyki medycznej fenomenów kulturowych.

\section{KONKLUZJA}

Etnografia przedtekstowa to wymagająca propozycja metodologiczna. Postrzegam ją jako apel i wyzwanie dla współczesnej humanistyki, jako projekt łączący tradycje etnografii semiotycznej, a następnie refleksyjnej z badaniami zainspirowanymi przełomem fenomenologicznym i teorią ugruntowaną. Jest więc taka etnografia punktem spotkania trzech nauk - antropologii, filozofii i socjologii. Jej podstawy nie są we współczesnej antropologii przełomowe, choć ich zastosowanie w ramach zwartej propozycji przenosi debatę metodologiczną na kolejny poziom. Etnografia przedtekstowa odkrywa przed badaczami pomijane fragmenty żywej rzeczywistości społecznej, dopełnia obrazy badanych kultur, wreszcie pozwala badać i widzieć inaczej, głębiej oraz bardziej cieleśnie. Jest więc nie tylko wyzwaniem stricte intelektualnym - wymaga także od badacza cielesnego i zmysłowego zaangażowania. Ciało jest przecież barierą ochroną - nie tylko przed światem fizyczno-biologicznym, ale również obcym kulturowo. Cielesne reakcje, takie jak spięcie i odczuwana niechęć sensoryczno-mięśniowa, towarzyszą też badaczom w terenie. Etnografia przedtekstowa uświadamia jednak, że takie cielesne zjawiska są nie tylko obecne, ale również możliwe do refleksyjnego autopoznania, zawieszenia, a wreszcie przełożenia na praktykę badawczą. W tym właśnie upatruję fenomenologicznych korzeni etnografii przedtekstowej, tutaj widzę miejsce na ujęcie własnego świata w nawias. Wierzę, że do takiego właśnie procesu doszło w „Sofie”, a także już później, podczas analizy doświadczeń i prób zrozumienia, co jako zespół i jako poszczególni badacze ujrzeliśmy i czego tam doświadczyliśmy - razem, ale też osobno. Droga członków zespołu pracującego w Zdroju do wiedzy, okraszona doznaniem napięcia oraz porzuceniem pierwotnego planu badań, odpowiada również na pytanie postawione przez Tima Ingolda (2014, s. 384-385) - gdzie powstaje i gdzie jest praktykowana etnografia? Czy również podczas zajęć ze studentami, czy tylko w terenie? Bez wątpienia nasza droga etnograficznego poznania zaczęła się w Zdroju, lecz wcale tam się nie skończyła. Sądzę że rozpoznane fakty etnograficzne narodziły się przede wszystkim w ramach intensywnej i długotrwałej wymiany doświadczeń i myśli już po powrocie z terenu. A to przecież, jak zauważa Rakowski (2018, s. 18), jest dystynktywną cechą podejścia przedtekstowego, choć w moim odczuciu ogólnie typowego także dla innych szkół etnograficznych (np. dla szkoły semiotycznej), gdzie pobyt w terenie to tylko jeden $\mathrm{z}$ etapów budowania wiedzy.

Etnografia przedtekstowa jest zatem szczególną formą uświadomienia nieujętego jeszcze w rygorystyczne ramy, a jednak prowadzącego do naukowego poznania. To uświadomienie może przybierać formy ucieleśnione, gdy badacz zdaje sobie sprawę 
z cielesności i potrafi ją wykorzystać do pracy w terenie, ale również „paradygmatyczne", gdzie antropolog, dzięki uważnemu oglądowi detalu, nabywa świadomości pojęciowej o badanym świecie. Słowem - uświadamia sobie, jak ten świat mu się jawi i jak można w tym świecie nawigować.

Etnografia przedtekstowa, idąc za myślą Godlewskiego, dzięki „perspektywie radaru" pozwala widzieć więcej, nie zawęża - jak luneta - obrazu badanej rzeczywistości i jest otwarta na zróżnicowane komunikaty spływające ze świata do badacza. Jednak radar odsłania tylko obrys rzeczywistości, nie precyzuje jej cech i charakterystyk, wskazuje jedynie położenie lub uwidacznia ruch obiektu. A przecież o sile etnografii świadczy zdolność dostrzegania oraz rozumienia lokalnych i gęstych „faktów” o ludzkich życiach i światach. Dlatego zaproponowałem, aby strategię lunety i radaru zastąpić po prostu generalną uwagą o sednie etnografii, którą Hastrup (2004) uważa za robioną tak, jak trzeba: etnografia to przede wszystkim stały kontakt z rzeczywistością, wolny od konieczności wybierania między tylko dwiema alternatywami. Taka orientacja to zdolność do metodologicznego balansu, do stałej i uważnej refleksji na temat terenu, ludzi i naszej pozycji w tej złożonej sieci relacji i zależności. Za jej pomocą można poszukiwać intersubiektywnej przestrzeni spotkania między nami a ludźmi, których chcemy zrozumieć. W tej właśnie przestrzeni toczą się badania etnograficzne, rodzą etnograficzne fakty i doświadczenia, powstaje rys jeszcze niespisanego, żywego i ucieleśnionego episteme.

Wracam więc do punktu wyjścia - do głębokiej redefinicji pojęcia terenu, który, tak jak doświadczenie przedtekstowe, jest otwarty i stale konstruowany. Sądzę, że te dwie sprawy - dynamicznie pojmowany teren i etnografia przedtekstowa - stanowią element tej samej myśli dekonstruującej paradygmat etnograficzny. W tym więc sensie etnografia przedtekstowa jest apelem o powrót do źródeł myśli refleksyjnej i krytycznej, apelem, który przypomina, że nie istnieje inny przepis na etnografię poza tym, że należy otwarcie i refleksyjnie podążać za terenem, jego specyfiką i żyjącymi tam ludźmi, przy jednoczesnym uznaniu, że to nieprzeźroczysty badacz - w tym także jego cielesność i wielozmysłowość - jest źródłem i narzędziem poznania antropologicznego.

\section{LITERATURA}

B l a ckb o u r n D a vid 2002, Fashionable Spa Towns in Nineteenth-Century Europe, [w:] S. Anderson, B. Tabb (red.), Water, Leisure \& Culture, Berg, Oxford, New York, s. 9-22.

Carrese Joseph, Marshall Patricia A. 2000, Teaching Anthropology in the Medical Curriculum, The American Journal of Medical Sciences, nr 319(5), s. 297-305.

Clifford Ja mes 2000, Kłopoty z kultura. Dwudziestowieczna etnografia, literatura i sztuka, tłum. E. Dżurak, J. Iracka, E. Klekot, M. Krupa, S. Sikora, M. Sznajderman, Wydawnictwo KR, Warszawa.

Cymer A n n a 2013, Piramidy w polskich górach, [w:] J. Kusiak, B. Świątkowska (red.), Miasto-Zdrój. Architektura i programowanie zmystów, Fundacja Bęc Zmiana, Warszawa, s. 319-323.

D un n Elizabeth C. 2008a, Prywatyzujac Polskę. O bobofrutach, wielkim biznesie i restrukturyzacji pracy, tłum. P. Sadura, Wydawnictwo Krytyki Politycznej, Warszawa. 
Dunn Elizabeth C. 2008b, Subjectivity after Socialism: An Invitation to Theory Building in Anthropology, [w:] I. Schröder, A. Vonderau (red.), Changing Economies and Changing Identities in Postsocialist Eastern Europe, LIT Verlag, Berlin, s. 225-235.

Fabre ga Hor a c i o 1980, Disease and Social Behavior: An Interdisciplinary Perspective, The MIT Press, Cambridge.

F a brega Hor a ci o, Silve r D a n i l B. 1973, Illness and Shamanistic Curing in Zinacantan. An Ethnomedical Analysis, Stanford University Press, Stanford.

Farmer Jan e, Kil patri ck S u e 2009, Are Rural Health Professionals also Social Entrepreneurs?, Social Science \& Medicine, nr 69(11), s. 1651-1658.

F r a $\mathrm{k}$ A r th u r 1995, The Wounded Storyteller. Body, Illness and Ethics, University of Chicago Press, Chicago.

Gandy Matthew 2013, O „miejskim metabolizmie” na nowo. Woda, przestrzeń i nowoczesne miasto, [w:] J. Kusiak, B. Świątkowska (red.), Miasto-Zdrój. Architektura i programowanie zmysłów, Fundacja Bęc Zmiana, Warszawa, s. 339-362.

Garro Lin d a 2000, Cultural Knowledge as Resource in Illness Narratives: Remembering through Accounts of Illness, [w:] Ch. Mattingly, L.C. Garro (red.), Narrative and the Cultural Construction of Illness and Healing, University of California Press, Berkeley-Los Angeles-London, s. 70-87.

Gee rtz Clifford 2005a, Opis gęsty: w poszukiwaniu interpretatywnej teorii kultury, [w:] tegoż, Interpretacja kultur. Wybrane eseje, tłum. M.M. Piechaczek, Wydawnictwo Uniwersytetu Jagiellońskiego, Kraków 2005, s. 35-58.

Ge ertz Clifford 2005b, Głęboka gra: walki kogutów na Bali, [w:] tegoż, Interpretacja kultur. Wybrane eseje, tłum. M.M. Piechaczek, Wydawnictwo Uniwersytetu Jagiellońskiego, Kraków 2005, s. $461-510$.

Godlewski Grzegor z 2016, Luneta i radar. Szkice z antropologicznej teorii kultury, Wydawnictwa Uniwersytetu Warszawskiego, Warszawa.

G od lew sk i Grzegor z 2018, Poza nachylenie tekstowe, w stronę doświadczenia przedtekstowego. Wskazówki terapeutyczne, Teksty Drugie, nr 1, s. 61-78.

G o o d B y r o n J. 1994, Medicine, Rationality and Experience. An Anthropological Perspective, Cambridge University Press, Cambridge.

Hahn Robert, Klein man A rthur 1983, Biomedical Practice and Anthropological Theory: Frameworks and Directions, Annual Review of Anthropology, nr 12, s. 305-333.

Hastrup Kirsten 2004, Getting it Right. Knowledge and Evidence in Anthropology, Anthropological Theory, nr 4(4), s. 455-472.

Hastrup Kirsten 2018, Muscular Consciousness. Knowledge-making in an Arctic Environment, [w:] T. Rakowski, H. Patzer (red.), Pre-Textual Ethnographies. Challenging the Phenomenological Level of Anthropological Knowledge-Making, Sean Kingston Publishing, Canon Pyon, s. 116-137.

Herzfeld Michael 1987, Anthropology through the Looking-Glass. Critical Ethnography in the Margins of Europe, Cambridge University Press, Cambridge.

Herzfeld Michael 2004, Antropologia. Praktykowanie teorii w kulturze i społeczeństwie, tłum. M. Piechaczek, Wydawnictwo Uniwersytetu Jagiellońskiego, Kraków.

In gold Ti m 2014, That's Enough about Ethnography!, HAU: Journal of Ethnographic Theory, nr 4(1), s. 383-395.

Kairski Mariusz, Buliński Tarzycjusz 2013, Pytanie o teren w antropologii, [w:] M. Kairski, T. Buliński (red.), Teren $w$ antropologii. Praktyka badawcza we współczesnej antropologii, Wydawnictwo Naukowe UAM, Poznań, s. 9-26.

Kilpat rick S u e et a l. 2009, Boundary Crossers, Communities, and Health: Exploring the Role of Rural Health Professionals, Health \& Place, nr 15(1), s. 284-290. 
Kulak Teresa, Czapliński Mariusz 1992, Zakopane i Krynica - życie kulturalne dwu polskich stacji klimatycznych na przełomie wieków. Próba porównania, Śląski Kwartalnik Historyczny Sobótka, t. 47, s. 279-290.

Nycz Rys zard 2018, Odkrywanie zmysłu udziału, Teksty Drugie, nr 1, s. 7-15.

Rakowski Tomas z 2018, Etnografia przedtekstowa. Fenomenologiczne korzenie interpretacji antropologicznej, Teksty Drugie, nr 1, s. 16-39.

Rakowski Tomasz, Patzer Helena 2018, Pre-textual Ethnography and the Challenge of Phenomenological Knowledge-making, [w:] T. Rakowski, H. Patzer (red.), Pre-Textual Ethnographies. Challenging the Phenomenological Level of Anthropological Knowledge-Making, Sean Kingston Publishing, Canon Pyon, s. 1-24.

R h o d e s L o r n a A. 1996, Studying Biomedicine as a Cultural System, [w:] C.F. Sargent, T.M. Johnson (red.), Medical Anthropology: A Handbook of Theory and Method. Revised Edition, Greenwood PG, London, s. 165-180.

Riska Elianne, Novelsaite Aurelija 2011, Professionalism and Medical Work in a Post-Soviet Society: Between Four Logics, Anthropology of East Europe Review, nr 29(1), s. 82-93.

S a ckett D avid L. 1997, Evidence Based Medicine, Seminars in Perinatology, nr 21(1), s. 3-5.

S e n nett Rich ard 2015, Ciało i kamień. Człowiek i miasto w cywilizacji Zachodu, tłum. M. Konikowska, Wydawnictwo Aletheia, Warszawa.

Speier A my 2011, Health Tourism in a Czech Health Spa, Anthropology \& Medicine, nr 18(1), s. $55-66$.

Speier Amy, Šmídová Iva, Wierciński Hubert 2014, Health and Medicine: Post-socialist Perspectives, Czech Sociological Review, nr 50(6), s. 815-820.

S t e w a r d Jill 2002, The Culture of the Water Cure in Nineteenth-Century Austria, [w:] S. Anderson, B. Tabb (red.), Water, Leisure \& Culture, Berg, Oxford, New York, s. 23-36.

S z mitkowska Agat a 2018, Architektura pracowniczych ośrodków wczasowych w Polsce. Zarys problematyki, Architectus, nr 3(55), s. 83-100.

Turner Victor 1986, The Anthropology of Performance, Performing Arts Journal Publications, New York.

Vonde ra u A s a 2008, Models of Success in the Free Market: Transformations of the Individual Self-Representations of the Lithuanian Economic Elite, [w:] I. Schröder, A. Vonderau (red.), Changing Economies and Changing Identities in Postsocialist Eastern Europe, LIT Verlag, Berlin, s. 111-128.

We is z Ge or ge 2011, Afterword. Historical Reflections on Medical Travel, Anthropology \& Medicine, nr 18(1), s. 137-144.

Wę cław owicz-Bil sk a Elż bi et a 2013, Mieszkać w uzdrowisku, [w:] J. Kusiak, B. Świątkowska (red.), Miasto-Zdrój. Architektura i programowanie zmysłów, Fundacja Bęc Zmiana, Warszawa, s. 303-306.

W iś n i e w s k i M i c h ał 2013, Architektura uzdrowisk Beskidu Sądeckiego, [w:] A. Szczerski (red.), Modernizmy. Architektura nowoczesności w II Rzeczypospolitej, t. 1, Dodo Editor, Muzeum Śląskie, Kraków, s. 311-338.

W i e r c iń s ki H u b e r t 2016, Etnograf w szpitalu. Uwagi na temat kłopotów z biomedycyną, Zeszyty Etnologii Wrocławskiej, nr 2(25), s. 71-92.

Wierciński Hubert 2017, „Children of the Transformation” - An Ethnography of Healthcare Reform and Polish Primary Care, Zeitschrift für Ethnologie, nr 142(1), s. 23-48.

Wi e r ciński H u b e r t 2019, Are Polish Primary Care Practitioners Social Entrepreneurs?, Ethnologia Polona, nr 40, s. 169-186.

Wi e r c iński H u bert 2020, Who are the „Expanded Doctors”? The Ethnography of Professional Self-Identifications in Polish Primary Care, Český Lid, nr 1(107), s. 23-49. 
HUBERT WIERCIŃSKI

\section{A TELESCOPE, RADAR OR MAGNIFIER? POSSIBILITIES FOR PRE-TEXTUAL ETHNOGRAPHY IN HEALTHCARE RESEARCH}

Keywords: pre-textual ethnography, medical anthropology, methodology, Poland

In the article I explore the concept of "pre-textual" ethnography. While seeking possibilities for its application, I analyse potential limitations of the latter. I use my own research experiences form Zdrój and Podstawowa Opieka Zdrowotna (POZ, Basic Healthcare). I consider these projects as embedded in two contrasting methodological traditions spanned between post-semiotic analyses and phenomenologically influenced anthropology. I argue, that the choice of methodological orientation should be preceded by careful analyses of the fieldwork characteristics. I consider this scrutiny as reflexive, magnifying and open for various stimulius coming to researcher from the investigated word, and thus, as a main pretextual tool in current anthropology.

H.W.

Dane Autora:

Dr Hubert Wierciński

Instytut Etnologii i Antropologii Kulturowej UW

Żurawia 4, 00-503 Warszawa

E-mail: hubertwier@gmail.com

ORCID: https://orcid.org/0000-0002-9535-4180 